\title{
PEMANFAATAN OBAT TRADISIONAL DENGAN PERTIMBANGAN MANFAAT DAN PENGENALAN PROFESI APOTEKER KEPADA SISWA SMAN 1 PANGKALANBUN KOTAWARINGIN BARAT
}

\author{
Brilliyanti Monica ${ }^{1}$ M. Arsyad Rahimamullah ${ }^{2}$ Yermia Diana $^{3}$ \\ ${ }^{123}$ STIKes Borneo Cendekia Medika Pangkalan Bun \\ ${ }^{1}$ Email : brillyantimonica@yahoo.co.id
}

\begin{abstract}
ABSTRAK
Obat tradisional merupakan warisan budaya bangsa yang perlu terus dilestarikan dan dikembangkan untuk menunjang pembangunan kesehatan sekaligus untuk meningkatkan perekonomian rakyat. Obat tradisional ini tentunya sudah diuji bertahun-tahun bahkan berabad-abad sesuai dengan perkembangan kebudayaan bangsa Indonesia, (Notoatmodjo, 2007).Pengobatan stroke dengan menggunakan tanaman obat memiliki beberapa fungsi diantaranya mencegah serangan stroke, memperbaiki (memperkuat) jaringan sel dan pembuluh darah di otak agar tidak pecah, memperbaiki kerusakan jaringan sel otak dan sel-sel saraf paska serangan stroke serta memperbaiki dan menormalkan kembali sistem jaringan tubuh yang tidak berfungsi akibat stroke (Nabyl, 2012). Metode yang digunakan selama kegiatan yaitu penyuluhan. Setelah kegiatan program pengabdian kepada masyarakat pada siswa SMAN 1 PangkalanBun ini terlaksana, siswa menjadi mengerti dan faham tentang profesi apoteker serta perananya dalam bidang kesehatan dan dan mengerti cara memanfaatkan obat tradisional dengan baik dan benar.
\end{abstract}

Kata Kunci : obat, apoteker

\section{TRADITIONAL MEDICINE UTILIZATION WITH CONSIDERATION OF BENEFITS AND INTRODUCTION OF THE PHARMACY PROFESSION TO STUDENTS SMAN 1 PANGKALANBUN KOTAWARWANT WEST}

\begin{abstract}
Traditional medicine is a cultural heritage of the nation that needs to continue to be preserved and developed to support the development of health and to improve the economy of the people. This traditional medicine has certainly been tested many years and even centuries according to the cultural development of the Indonesian nation, (Notoatmodjo, 2007). Treatment of stroke by using medicinal plants has several functions including preventing stroke attacks, improving (strengthening) the tissues of cells and blood vessels in the brain to avoid rupture, repair tissue damage to brain cells and nerve cells Post-attack stroke and repair and normalize the body tissues system that is not functioning due to stroke (Nabyl, 2012). Methods used during the activity are counseling. After the activities of Community devotion program on the students of SMAN 1 PangkalanBun is done, students become familiar and understand about the profession of pharmacists and their clothes in the field of health and understand how to utilize traditional medicines with Good and true.
\end{abstract}

Keywords: medicine, pharmacist 


\section{PENDAHULUAN}

Obat tradisional di Indonesia sangat besar peranannya dalam pelayanan kesehatan masyarakat di Indonesia, sehingga obat tradisional sangat berpotensi untuk dikembangkan. Indonesia kaya akan tanaman obat-obatan, yang mana masih belum dimanfaatkan secara optimal untuk kesehatan. Indonesia diketahui memiliki keragaman hayati terbesar kedua di dunia setelah Brasil (Notoatmodjo, 2007).

Obat tradisional merupakan warisan budaya bangsa yang perlu terus dilestarikan dan dikembangkan untuk menunjang pembangunan kesehatan sekaligus untuk meningkatkan perekonomian rakyat. Obat tradisional ini tentunya sudah diuji bertahun-tahun bahkan berabadabad sesuai dengan perkembangan kebudayaan bangsa Indonesia, (Notoatmodjo, 2007).

Pengobatan stroke dengan menggunakan tanaman obat memiliki beberapa fungsi diantaranya mencegah serangan stroke, memperbaiki (memperkuat) jaringan sel dan pembuluh darah di otak agar tidak pecah, memperbaiki kerusakan jaringan sel otak dan sel-sel saraf paska serangan stroke serta memperbaiki dan menormalkan kembali sistem jaringan tubuh yang tidak berfungsi akibat stroke (Nabyl, 2012).

$\begin{array}{lcr}\text { Indonesia } & \text { merupakan } & \text { negara } \\ \text { besar yang terkenal } & \text { karena } \\ \text { keanekaragamannya, salah } & \text { satunya } \\ \text { adalah } \quad \text { keanekaragaman } & \text { hayati }\end{array}$ (megabiodiversity) khususnya tumbuhan. Selain itu Indonesia juga memiliki keanekaragaman etnis yang memiliki berbagai macam pengetahuan tentang obat tradisional yang menggunakan bahan-bahan dari tumbuhan. Banyak dari jenis tumbuhan itu telah ribuan tahun digunakan oleh nenek moyang bangsa Indonesia dan dokter sebagai bahan obat atau jamu tradisional untuk berbagai macam penyakit dan memberikan hasil yang baik bagi pemeliharaan kesehatan serta pengobatan (Mills, 1996).

Di bumi ini diperkirakan terdapat 40.000 spesies tumbuhan. Dari jumlah tersebut sekitar 30.000 spesies hidup di kepulauan Indonesia dan sekurang-kurangnya 9.600 spesies diketahui berkhasiat obat, tetapi baru 300 spesies yang telah dimanfaatkan sebagai bahan baku obat tradisional dan industri obat tradisional (Kemenkes RI, 2007).

Keragaman zat kimia penyusun tumbuh-tumbuhan atau zat yang dihasilkan tumbuhan merupakan kelebihan tanaman, sehingga sebagai tanaman obat dapat menghasilkan aktivitas yang luas dan memiliki sisi positif pada tubuh karena tidak memiliki efek samping seperti halnya obat-obat kimiawi (Mills, 1996).

Dalam perkembangan pelayanan farmasi telah terjadi pergeseran orientasi dari produk menjadi orientasi kepentingan pasien. Hal ini dilatarbelakangi oleh perkembangan ilmu pengetahuan dan teknologi di bidang kesehatan serta tuntutan terhadap jaminan keselamatan pasien yang semakin kuat. Orientasi ini dikenal dengan konsep Pharmaceutical Care. Tentunya tanpa mengesampingkan produk. Dengan banyak ditemukannya masalah yang berkaitan dengan obat dan penggunaannya; semakin meningkatnya keadaan sosio-ekonomi dan tingkat pendidikan masyarakat; serta adanya tuntutan dari masyarakat 
akan pelayanan kefarmasian yang bermutu, Pharmaceutical Care merupakan hal yang mutlak diterapkan.

\section{METODE PENELITIAN}

1. Penyuluhan dan Pengenalan Obat Tradisonal dan penggunaanya kepada siswa/i SMAN 1 PangkalanBun Kotawaringin Barat.

2. Penyuluhan dan Pengenalan sediaan farmasi dan cara penggunaanya yang benar kepada siswa/i SMAN 1 PangkalanBun Kotawaringin Barat.

3. Penyuluhan dan Pengenalan Profesi Apoteker kepada siswa/i SMAN 1 PangkalanBun Kotawaringin Barat.

\section{HASIL DAN PEMBAHASAN}

Ketersediaan tenaga kesehatan yang bermutu dalam jumlah yang memadai sangat penting bagi pembangunan kesehatan di daerah untuk mencapai tujuan pembangunan kesehatan secara lebih baik. Departemen Kesehatan Republik Indonesia (Depkes RI) (2009) menyatakan bahwa tujuan pembangunan sektor kesehatan adalah meningkatkan kesadaran, kemauan dan kemampuan hidup sehat bagi setiap orang supaya terwujud derajat kesehatan masyarakat yang setinggitingginya. Untuk itu, distribusi tenaga kesehatan dan juga pengetahuan generasi muda yang memadai dibutuhkan agar masyarakat di daerah dapat mengerti dan menikmati pelayanan kesehatan yang lebih baik dengan akses yang relatif mudah. Dampak positifnya adalah mereka menjadi lebih mungkin hidup di lingkungan masyarakat dengan perilaku yang jauh lebih sehat, selain itu minat geerasi muda terhadap profesi tenaga keseatan semakin meningkat. Terkait pentingnya tenaga kesehatan, salah satu unsur penting yang berperan dalam penyelenggaraan pembangunan kesehatan adalah sumber daya manusia (SDM) kesehatan. Selain itu, dalam SKN 2012, ada tujuh subsistem yang menentukan pencapaian derajat kesehatan secara nasional, yaitu administrasi kesehatan, informasi kesehatan, sumber daya kesehatan, upaya kesehatan, pembiayaan kesehatan, peran serta dan pemberdayaan masyarakat, ilmu pengetahuan dan teknologi kesehatan, dan pengaturan hukum kesehatan. Ini menunjukkan bahwa ketersediaan dan distribusi tenaga kesehatan yang memadai sangat dibutuhkan untuk mencapai tujuan pembangunan kesehatan nasional.

SDM kesehatan adalah orang yang bekerja secara aktif di bidang kesehatan. Menurut Adebayo dan Oladeji (2006, dalam Ademiluyi et al., 2009), SDM kesehatan terdiri dari dokter, apoteker, perawat, bidan, ahli teknologi laboratorium, administrator, akuntan dan para pekerja kesehatan lainnya. SDM kesehatan yang bermutu dalam jumlah yang memadai perlu distribusikan secara merata serta bermanfaat secara optimal dalam upaya menjamin keterlaksanaan pembangunan kesehatan dalam meningkatkan derajat kesehatan masyarakat yang setinggi-tingginya. Akan tetapi, generasi muda masih banyak yang belum memahami tentang tenaga kesehatan dan profesi kesehatan.

Profesi apoteker merupaan salah satu teaga kesehatan yang sangat penting dan tidak dapat dianggap remeh 
peranannya. Pemerintah mengatur profesi apoteker ini dalam peraturan pemerintah NOMOR 51 TAHUN 2009 tentang Pekerjaan Kefarmasian. Dalam Peraturan Pemerintah ini yang dimaksud dengan:

1. Pekerjaan Kefarmasian adalah pembuatan termasuk pengendalian mutu Sediaan Farmasi, pengamanan, pengadaan, penyimpanan dan pendistribusi atau penyaluranan obat, pengelolaan obat, pelayanan obat atas resep dokter, pelayanan informasi obat, serta pengembangan obat, bahan obat dan obat tradisional.

2. Sediaan Farmasi adalah obat, bahan obat, obat tradisional dan kosmetika.

3. Tenaga Kefarmasian adalah tenaga yang melakukan Pekerjaan Kefarmasian, yang terdiri atas Apoteker dan Tenaga Teknis Kefarmasian.

4. Pelayanan Kefarmasian adalah suatu pelayanan langsung dan bertanggung jawab kepada pasien yang berkaitan dengan Sediaan Farmasi dengan maksud mencapai hasil yang pasti untuk meningkatkan mutu kehidupan pasien.

5. Apoteker adalah sarjana farmasi yang telah lulus sebagai Apoteker dan telahmengucapkan sumpah jabatan Apoteker.

6. Tenaga Teknis Kefarmasian adalah tenaga yang membantu Apoteker dalam menjalani Pekerjaan Kefarmasian, yang terdiri atas Sarjana Farmasi, Ahli Madya Farmasi, Analis Farmasi, dan Tenaga Menengah

Farmasi/Asisten Apoteker.

Dari kegiatan ini diketahui bahwa siswa/i SMAN 1 PangkalanBun ternyata masih belum memahami tentang peran dan profesi apoteker. Hampir seluruh siswa belum mengerti dan faham tentang profesi apoteker serta perananya dalam bidang kesehatan menurut peraturan pemerintah NOMOR 51 TAHUN 2009 tentang Pekerjaan Kefarmasian. Setelah kegiatan ini terlaksana, siswa menjadi mengerti dan faham tentang profesi apoteker serta perananya dalam bidang kesehatan. Hal itu ditandai dengan siswa mampu menjawab pertanyaan tentang profesi apoteker serta perananya dan mengerti cara memanfaatkan obat tradisional dengan baik dan benar.

\section{KESIMPULAN DAN SARAN}

Setelah kegiatan program pengabdian kepada masyarakat pada siswa SMAN 1 PangkalanBun ini terlaksana, siswa menjadi mengerti dan faham tentang profesi apoteker serta perananya dalam bidang kesehatan dan dan mengerti cara memanfaatkan obat tradisional dengan baik dan benar.

Efek samping obat tradisional relatif kecil jika digunakan secara tepat, yang meliputi kebenaran bahan, ketepatan dosis, ketepatan waktu penggunaan, ketepatan cara penggunaan, ketepatan telaah informasi, dan tanpa penyalahgunaan obat tradisional itu sendiri.

Penelitian yang telah dilakukan terhadap tanaman obat sangat membantu dalam pemilihan bahan baku obat tradisional. Pengalaman empiris ditunjang dengan penelitian 
semakin memberikan keyakinan akan khasiat dan keamanan obat tradisional.

\section{DAFTAR PUSTAKA}

BPOM RI, Pedoman Cara Pembuatan Obat Tradisional Yang Baik, $h$ t t p : //pom.go.id/pub lic/hukum_perundan $g a n$ / $p d f$ / SK\%20CPOTB(1).pdf, diakses Juli 2018.

WHO, 2003, Traditional medicine, http://www.who.int/mediacentr el factsheets/fs134/en/, diakses Juli 2018.

Sukandar E Y, Tren dan Paradigma Dunia Farmasi, IndustriKlinik- Teknologi Kesehatan, disampaikan dalam orasi ilmiah Dies Natalis ITB, http://itb.ac.id/focus/ focus_file/orasi-ilmiah-dies45.pdf, diakses Juli 2018.

Sastroamidjojo S, 2001, Obat Asli Indonesia, Dian Rakyat, Jakarta, 170.

Suarni, 2005, Tanaman Obat tak Selamanya Aman, http://pikiranrakyat. com, Juli 2018.

Hariana, Arief. 2004. 2009. Tumbuhan Obat dan Khasiatnya Seri 1, 2, dan 3. Jakarta, Penebar Swadaya.

Zuhud, Ervizal A.M., dan A. Hikmat. 2009. Hutan Tropika Indonesia
Sebagai Gudang Obat Bahan Alam Bagi Kesehatan Mandiri Bangsa. Bunga Rampai Biofarmaka Kehutanan Indonesia dari Tumbuhan Hutan untuk Keunggulan Bangsa dan Negara. Pusat Litbang Hutan Tanaman. Bogor.

Nogroho, I.A. 2010. Lokakarya Nasional Tumbuhan Obat Indonesia. Apforgen News Letter Edisi 2 Tahun 2010. http:/// www. forplan.or.id. Diakses tanggal Juli 2018.

Krismawati, A. dan M.Sabran, 2004. Pengelolaan Sumberdaya Genetik Tanaman Obat Spesifik Kalimantan Tengah. Buletin Plasma Nutfah 12 (1). Palangkaraya. 